\title{
Values and Value Priorities Underlying Japanese Elementary-School Moral Education: Content Analysis of Japanese Elementary-School Moral Books
}

\author{
Shinobu Anzai \\ Assistant Professor of Japanese, Languages and Cultures Department \\ United States Naval Academy, Annapolis, Maryland USA \\ Email: anzai@usna.edu \\ Chie Matsuzawa \\ Associate Professor of Japanese, Languages and Cultures Department \\ United States Naval Academy, Annapolis, Maryland USA \\ Email: chiepaik@usna.edu
}

Doi:10.5901/mjss.2014.v5n4p359

\begin{abstract}
Japan has seen controversy over moral education. Generally, Japanese moral education is regarded as a menace to the development of true democracy and multiculturalism. Moral education in the Meiji period and in the years leading to and during the Second World War was blamed for the country's fanatical militarism and nationalism. Postwar democratic reforms ended moral education; however, traditional moral values continued to guide people's lives. At that time Japanese moral values were criticized for contributing to the shaping of shared cultural consciousness and common national identity, suggesting Japan's cultural superiority over other cultures. In 2006, the Fundamental Law of Education of 1947 (FLE), which defined the principles for post-war Japanese education, was revised. It stipulated the importance of teaching Japanese traditions and culture with special emphasis on moral education. The return of moral education has provoked fear and suspicion of a return to past militarism and nationalism. Hitherto, discussions on Japanese moral education have entailed strong political overtones. However, few have actually studied the content of the books used in moral education. The present study examined Japanese elementary-school moral books published in 2008 to identify types of values transmitted therein. Content analysis of the moral books has revealed that the values presented in the moral books are congruent with universal human values recognized across cultures around the world. Confucianism and Buddhism explain values absent from the moral books. The influence of Shinto is also found. The paper discusses the findings in reference to the theory of universal human values and the Japanese cultural heritage.
\end{abstract}

Keywords: values; moral education; content analysis

\section{Introduction}

Japan has seen controversy over moral education. Generally, Japanese moral education is regarded as a menace to the development of true democracy and multiculturalism (Luhmer, 1990; Hoffman, 1999; Khan, 1997; McVeigh, 1998). Moral education in the Meiji period and in the years leading to and during the Second World War was blamed for Japan's fanatical militarism and nationalism. Postwar democratic reforms ended moral education; however, traditional moral values continued to guide people's lives. At that time Japanese moral values were criticized for contributing to the shaping of common national identity, suggesting Japan's cultural superiority over other cultures. In 2006, the Fundamental Law of Education of 1947 (FLE), which defined the principles for post-war Japanese education, was revised. It stipulated the importance of teaching Japanese traditions and culture with special emphasis on moral education. The return of moral education has provoked fear and suspicion of a return to past militarism and nationalism. Hitherto, discussions on Japanese moral education have entailed strong political overtones. However, few have actually studied the content of the books used in moral education. The present study examined Japanese elementary-school moral books to identify types of values transmitted therein. In understanding the values, the present study draws on the theory of universal human values. Universal values are values that "a great many human beings in the vast majority of places and situation, at almost all times, do in fact hold in common, whether consciously and explicitly or as expressed in their behavior" (Berlin cited in Jahanbegloo, 1991). The theory of universal human values postulates that all human 
beings share common values derived from basic human needs that must be fulfilled for survival both as individuals and groups. The theory further suggests a high degree of agreement across culture concerning a value hierarchy, that is, values expressing collective concerns are placed higher than those expressing individual concerns. These theoretical premises provide a springboard for the present study.

Specifically, the present study addressed the following questions. First, do Japanese elementary-school moral books capture the universal values and the value hierarchy recognized across cultures around the world? Second, do the Japanese moral books omit any values universally recognized? If so, what are they? Third, do the Japanese moral books present any Japan-specific value(s) not universally recognized? If so, what are they? Findings of the study should yield insight into the value contents of the most recent Japanese elementary school moral education.

\section{Background}

Traditional Japanese education aims at perfection of character through the development of mental, moral and physical development. Individually, each is referred as chi-iku (cognitive development), toku-iku (development or virtue) and tai$i k u$ (physical development), and collectively san-iku (three developments). Among the three core developments, moral education addressing development of virtue has attracted much attention from scholars and educators in and outside the country.

In modern Japanese history, the issue of moral education invariably arose when the country was going through unparalleled social and cultural changes as results of the country's contacts with outside cultures, predominantly the West. Two significant contacts with the West took place first in the Meiji period (1868-1914) and again after World War II. These contacts undeniably transformed Japan into today's modern and democratic state. However, the process of transformation was accompanied by a struggle to maintain Japan's own sovereignty and cultural identity, and both times the country turned to moral education for spiritual sustenance. Today, Japan is facing a new influx of foreign culture called globalization. As this force influences the country in unpredictable and sometimes not easily visible ways, Japan once again seeks to affirm its identity, and moral education is once again called on to define what and how the country should be. The majority of Japanese people agree on the necessity of moral education in school; however, the content of moral education (what moral principles are to be taught) has been contested in the country ever since nation-wide moral education was first instituted in 1872. Two historic events in the nation mark shifts in the direction and nature of moral education in Japan. They are the Meiji Restoration in 1868 and Japan's surrender in 1945.

\subsection{Moral Education in the Meiji Period}

The Meiji Restoration (Meiji Ishin) in 1868 marked the end of the feudal system and the birth of Japan as a modern nation. Emerging from two centuries of seclusion, Japan swiftly undertook to restructure the nation following western models. To Japan, the West presented opportunities for "Civilization and Enlightenment" (Bunmei Kaika) but also the threat of colonization as evidenced by the British presence in China and French in Indochina at the time. Japan's strategy to counter the colonial powers of the West in the Meiji period (1886-1912) was building a "Wealthy Country and Strong Military" (fukoku kyōhei). While pursuing accelerated modernization and westernization, Japan also tried to strengthen its sovereignty by preserving its spiritual heritage through moral education. Etymologically, Meiji means "enlightened rule" and the goal of the period was to combine advanced "western learnings" with traditional "eastern values". Moral education was to complement the advanced science and technology of the west with the traditional spiritual trainings of the east. In 1872, the Education Law (gakusei) officially instituted moral education.

In the early Meiji period, moral education was open to western values. It took a hybrid approach in teaching values of the east through books on Confucian teachings and values of the west through books translated into Japanese (e.g., Moral Philosophy by American philosopher Winslow Habbard, The System of Moral Science by American author Laurence Hickok, Aesop's Fables, and Self-Help by Scottish author Samuel Smiles) (Sasaki, 1999). As advancing years brought resistance to further westernization, this hybrid approach was gradually replaced by one that based exclusively on Confucianism. The official pronouncement of Kyōgaku Seishi (the Imperial Will on Great Principles of Education) in 1879 made it clear that the traditional Confucian values were to serve as the foundation of moral education and public morals.

The history of Confucianism in Japan goes back to the $7^{\text {th }}$ century and Confucian moral and ethical principles held a strong grasp on the Japanese court and feudal governments. The first written law of Japan, the Seventeen-Article Constitution of 604, was an embodiment of Confucian teachings, and its first article 'Harmony should be valued and 
quarrels should be avoided" (Wa o motte tattoshi to nasu) has since become an axiom of social behavior in Japan (Umehara and Inamori, 2005). The Seventeen-Article Constitution was a list of precepts of social behavior for court officials and the people. These precepts may be understood as the government's first involvement in moral education in Japan. In the late $12^{\text {th }}$ century, as Japan entered a feudal era, Confucianism along with Buddhism provided a spiritual base for warriors, as witnessed in the virtues that embodied Bushido (the path of the warrior) - self-control, loyalty, sincerity, and politeness (Nitobe, 1969). Confucianism, which had come to Japan long before contact with the West, and the country as ruled by Confucianism signified the "authentic" Japan untouched by western influence.

The Meiji-era Kyōgaku Seishi (the Imperial Will on Great Principles of Education) met with resistance from proponents of modernization who feared that renewed emphasis on Confucianism would revive the old feudal order. They proposed alternatives including western moral philosophy, religion-based teachings, and Shinto (Monai, 2012). The 1890 Imperial Rescript on Education (Kyōiku Chokugo) presented a fusion of Confucian ideals of compassion, duty, loyalty and filial piety (jin-gi-chu-ko) with the Japanese ideal of the nation bonded by a benevolent father (the emperor) and his loyal subjects (people). This soon took a turn toward imperialism and fanatic nationalism that led Japan to wars in Asian countries and subsequently World War II.

\subsection{Moral Education after WWII}

After the war, democratic reforms abolished moral education. The U.S. Education Mission was sent Japan to "stop wrong teaching" and "provide teachers and schools to inform their minds without hardening their hearts." (Report of the US Education Mission, 1946). Their goal was to re-educate the entire population of Japan in order to build a democratic society through education, and in 1947 the Fundamental Law of Education was enacted under the direction of the occupying forces. Moral education was officially abolished then and it ceased to exist as a subject matter in the school curriculum. However, moral principles based on Confucianism continued to exert a strong influence on students' life in school and school-related activities. The Fundamental Law of Education of 1947 remained as Japan's educational constitution until 2006 when it was amended for the first time in sixty years since the end of WWII.

\subsection{Moral Education Today}

Most recently, Japan is facing a very different type of outside force in globalization. In the 1990s, Japan started feeling pressure to reform the country's education system to meet the new challenges of a post-industrial economy demanding advanced technology, knowledge-based society, and globalization (Ministry of Education, Culture, Sports, Science and Technology, hereafter MEXT, 2006). In 2006, Japan amended the Fundamental Law of Education in response to such demands. While the revised law addressed the importance of "broad knowledge" (habahiroi chishiki), "creativity" (sōzōsel), and "self-direction" (jiritsu no seishin), it also included the language "love of our country" (waga kuni o aisuru), "respect for tradition and culture" (dentō to bunka o sonchō) and "love of our homeland" (kyōdo o aisuru) (MEXT, 2006). Furthermore, the revised law officially declared moral education to be subject matter with clearly defined objectives and guidelines and restored the status of moral education to that of pre-war and war-time Japan. This met with strong criticism going so far as to declare that the revised Fundamental Law of Education did not reflect a democratic and constitutionally law-driven society as intended by the original law of 1947 but resembled in content and intent the Imperial Rescript on Education (Kyōiku Chokugo), a product of a wartime regime (Tamura, 2009). Subsequently, in 2008, MEXT published the Course of Study to provide guidelines on implementing moral education in elementary and secondary schools.

Hitherto, few studies have actually examined the content of the Japanese moral books. The present study attempts to add a new dimension to the debates by examining the content of moral books used in Japanese elementary schools and thereby identify types of values transmitted therein. In understanding the value content, the study draws on theories of universal human values.

\section{Cultural Perspectives on Moral Values}

Social psychologists have long investigated whether there are universal values and what those values are (e.g., Allport, 1961; Kluckhohn, 1951; Rockeach, 1973; Schwartz and Bilsky, 1990). They hypothesized that all humans would share common values derived from universal requirements of the human condition: biological needs (e.g., food and safety), social co-ordination needs (e.g., self-control, harmony), and needs related to group welfare and survival (e.g., tradition, 
obedience) (Schwartz \& Bilsky, 1987). These are universal values that people across places and situations, at almost all times, share, whether consciously and explicitly or as expressed in their behavior (Berlin cited in Jahanbegloo, 1991). Various studies along this line eventually led to the identification of a number of core values recognized and accepted by people over the world. Furthermore, a study (Schwartz \& Bardi, 2001) found a high level of consensus regarding a hierarchical order of the values and that the relative importance of the identified core values were quite similar from country to country. Values expressing collective concern (e.g., understanding and tolerance) were consistently ranked higher than values expressing individual concerns (e.g., power and achievement). This universal hierarchical order of values was attributed to the nature of human beings as primarily relational and social beings with the need to promote and preserve cooperative and supportive relations among members of a society (Schwartz, 1992, 1994). Spirituality (i.e., finding meaning in life) was originally hypothesized as a possible universal core value; however, it was not found to be recognized in all cultures (Schwartz, 1992, 2006).

There are ten (10) universal values recognized across culture (Schwartz \& Bilsky, 1987, 1990). They are: Selfdirection-independent thought and action; Stimulation-Excitement, novelty, and challenge in life; Hedonism—pleasure and gratification for oneself; Achievement-personal success through demonstrating competence according to social standards; Power-social status and prestige, control or dominance over people and resources; Security-safety, harmony, and stability of society, of relationships, and of self; Conformity—restraint of action, inclinations, and impulses likely to upset or harm others and violate social norms; Tradition-respect, commitment, and acceptance of the customs and ideas that traditional culture or religion provide; Benevolence-preserving and enhancing the welfare of those with whom one is in frequent contact, Universalism - understanding, appreciation, tolerance and protection for the welfare of all people beyond the primary group and for nature. Clearly, some values are characteristic of individualistic cultures wherein individuals are recognized as independent, autonomous beings with rights to pursue their own goals while others are characteristic of cultures wherein groups rather than individuals are the fundamental unit of social concern. Individually, people display greater differences in value priorities; however, remarkably, the study of Schwartz and Bardi (2001) involving nations around the world found a high level of consensus regarding the hierarchical order of the values and that the relative importance awarded to the ten universal values were quite similar from country to country. The Benevolence, Self-direction, and Universalism value types are consistently more important than the rest; the Power, Tradition, and Stimulation values types least important; Security, Conformity, Hedonism, and Achievement somewhere in between. Schwartz (2006) attributes this universal hierarchical order of values to the nature of human beings as primarily relational and social beings with needs to promote and preserve cooperative and supportive relations among members of a society. These premises provide the baseline on which the present study is conducted. The present study explores values expressed in the Japanese elementary school moral books in reference to the typology of universal human values.

\section{Description of the Study}

Six moral books, from first through sixth grade, adopted by the Board of Education in a prefecture in western Japan were obtained and read by two authors, both English-Japanese bilingual. These books were published in Japanese and they were used in 179 elementary schools and read by over 55,000 students. Unlike government-authorized textbooks, the moral books are not officially recognized as textbooks but were published in accordance with the guidelines provided by the Course of Study (Uetsugu, 2010). The Course of Study states the goal of moral education to cultivate students' morality in areas of disposition, judgment, engagement and attitude. It further shows the contents of moral education to include four areas of focus: about self (individuality), about relationships (interactions with others), about nature and sublime things (magnificence and wonder of nature), and about groups and society (rules and a sense of duty). The books were written by educators and experts in moral education in the region. Altogether, they contain 162 short stories. Typically, the moral stories comprise short narratives involving children of age close to the targeted grade level, concerning their friends, families, schools and communities and ultimately inspiring a positive change in the protagonist. Applying the principle of qualitative content analysis (Garaneheim \& Lundman, 2004), the six moral books, 162 stories were read by the researchers for extraction of the themes. To understand values, the extracted themes were coded and cross-referenced to the ten (10) universal values. To assess the value priorities of the moral books, the number of values and their frequencies of extraction were counted and recorded. Greater numbers of values counted indicated greater importance. Omissions of the ten values from the moral books were identified. Values presented in the moral books but not corresponding to any of the ten values were identified. Finally, the ten universal values were rank-ordered according to their frequency of mention from most frequent to less frequent. The values were coded in Japanese and translated into 
English by the first author and then checked by the second author for possible discrepancy. A third person, also bilingual in English and Japanese, back-translated the English translation of values to Japanese to assure accuracy of the translation.

\section{Findings}

Table 1 shows the values extracted from the six moral books consisting of 162 stories

Altogether, thirty-four (34) distinct values were identified representing altogether six (6) value categories. In the order of prominence from most- to least-frequently mentioned, they were: (1) Benevolence extracted 50 times, (2) Universalism extracted 41 times, (3-4) Conformity and Self-direction tied at third place, each extracted 22 times, and (56) Tradition and Security at fifth place, each extracted 6 times. Four (4) of the ten values not mentioned were: Stimulation, Hedonism, Achievement and Power. Of the six (6) values extracted from the moral books, all but one (i.e., Self-direction) were values typically associated with collective concerns. What follows is a description of each value category found in the moral books with representative synopses of stories in the moral books. They are presented in the order of prominence from most important to least important as indicated by the number of mentions extracted from the moral stories.

Table 1. Universal Human Values (Schwartz, 1992, 1994) and Japanese Moral Books

\begin{tabular}{|c|c|c|}
\hline $\begin{array}{c}\text { Universal } \\
\text { Human Values }\end{array}$ & Definition & Representation in the Japanese Moral Books \\
\hline $\begin{array}{l}\text { Benevolence } \\
(50)\end{array}$ & $\begin{array}{l}\text { Preserving and enhancing the welfare of those with home } \\
\text { on is in frequent contact }\end{array}$ & $\begin{array}{l}\text { love family, love school, love homeland, friendship, } \\
\text { helpful, kind, honest, sincere, responsible, foregoing, } \\
\text { considerate, cooperative }\end{array}$ \\
\hline $\begin{array}{l}\text { Universalism } \\
\qquad(41)\end{array}$ & $\begin{array}{l}\text { Understanding, appreciation, tolerance and protection for } \\
\text { the welfare of all people beyond the extended primary } \\
\text { group and for the nature }\end{array}$ & $\begin{array}{l}\text { respect others, love nature, love animals, volunteer, } \\
\text { humanitarianism, contribute to international } \\
\text { community }\end{array}$ \\
\hline Conformity (22) & $\begin{array}{l}\text { Restarting of action, inclinations, and impulses likely to } \\
\text { upset or ham others and violate social norms }\end{array}$ & $\begin{array}{l}\text { polite, self-restrain, respect parents, grateful for } \\
\text { parents, respect rules }\end{array}$ \\
\hline $\begin{array}{l}\text { Self-direction } \\
\text { (22) }\end{array}$ & $\begin{array}{l}\text { Independent thought and action-choosing, creating and } \\
\text { exploring, derived from needs for control, independence } \\
\text { and autonomy }\end{array}$ & $\begin{array}{l}\text { working hard, inventive, inquisitive, self-reliant, } \\
\text { diligent, resilient }\end{array}$ \\
\hline Tradition (6) & $\begin{array}{l}\text { Respect, commitment and acceptance of the customs } \\
\text { and ideas and beliefs that one's culture or religion } \\
\text { provides }\end{array}$ & respect tradition, grateful \\
\hline Security (6) & $\begin{array}{l}\text { Safety, harmony and stability of society, relationships and } \\
\text { self }\end{array}$ & clean, tidy, healthy \\
\hline Stimulation $(0)$ & Excitement, novelty and challenge in life & No representation \\
\hline Hedonism (0) & Pleasure or sensuous gratification for oneself & No representation \\
\hline Achievement (0) & $\begin{array}{l}\text { Personal success through demonstrating competence } \\
\text { according to social standards and prevailing cultural } \\
\text { standards, obtaining social approval }\end{array}$ & No representation \\
\hline Power (0) & $\begin{array}{l}\text { Social Status and prestige, dominance over people and } \\
\text { resources }\end{array}$ & No representation \\
\hline
\end{tabular}

\subsection{Value Content and Hierarchy of the Japanese Moral Books}

Benevolence (preserving and enhancing the welfare of those with whom one is in frequent contact, in-group): Collective concerns of Benevolence restrain impulses and inhibit actions that might hurt others. When children enter school, they first learn to be "kind", "helpful", "polite", "considerate", "honest" and "respectful" toward each other and follow rules so that all can learn and play in a safe and pleasant learning environment. Understandably, the moral stories relating to Benevolence are most abundant in the moral books. Some examples are:

A girl finds a lost ticket on a bench in the train station. She remembers an old woman with many packages sitting exactly at the same spot. She knows that the ticket belongs to the old woman and worries about her being detained at the exit gate of her destination. After talking to her mother and seeing the old woman's destination station printed on the 
ticket, she asks the station master to call the destination station so that the old woman can go through the exit gate without being stopped (a "good Samaritan" story in the 3 rd-grade moral book).

A poor boy named Lincoln living in the backwoods somewhere in America had no money to buy books and borrowed a book from his neighbor. One night, he went to bed, leaving the book on a desk by window. It rained hard that night. When Lincoln woke the next morning, he found the book wet and ruined by the rain having seeped through the roof and wall of his house. Lincoln feared the ire of the book's owner. However, Lincoln confessed to his neighbor, asking forgiveness and offering to do farm work to repay him back for the book. For his honesty and courage, Lincoln was forgiven and rewarded with the book he loved so much (a story teaching "honesty" also found in the $3^{\text {rd }}$ grade moral book.).

Every Sunday, a girl takes a walk with her grandmother. By the road, she sees the flowers tended by people in the community are blooming. Down the road, there is a small river by which animals make their home. In the park is a big old tree that has been there ever since the grandmother was a little girl. The girl knows that the tree has been looking over her town all these years. The girl loves her town very much. (Teaching love for homeland in the 1 st grade moral book)

Universalism (understanding, appreciation, tolerance and protection for the welfare of all people beyond the extended primary group and for nature): In school, children are made aware of communities in their immediate surroundings and beyond. "Humanitarianism" and "volunteering" are examples of values in this category found in the moral books.

Mr. Okada is an elderly volunteer serving the community as a guide in a municipal park. Over years of volunteer work, he wrote a guidebook containing a history of the park, interesting stories, and useful information, so that people visiting the park will enjoy and learn more about the park. Mr. Okada says, "I am the happiest of men when people visit the park and enjoy my stories (a story of "volunteerism" in the 6 6 th-grade moral book).

Japanese love of nature is well known as revealed in various forms of art, literature, architecture and gardening. These are manifestation of Shinto (the path of deities) beliefs, a tradition indigenous to Japan. Shinto recognizes the power of nature and the souls of the dead (Litteton, 2002) and teaches living a simple life harmonious life nature and people both living and deceased. In essence, Shintō, like animism, recognizes divine spirits everywhere and in every being, in nature and in people and thereby commands respect for all beings in the universe. In Shinto belief, nature is sacred and natural objects such as trees, mountains, rocks and wind are worshipped as containing sacred spirits.

Snow-crowned Mt. Fuji moves people for its majestic beauty. Young people climbing Mt. Fuji do so to conquer the mountain. Conquering nature is a Western idea. In the Japanese tradition, nature is not to be conquered but befriended. Young people have forgotten respect and fellowship with nature (a story teaching reverence for nature in the $6^{\text {th }}$-grade moral book).

Conformity (restraint of action, inclinations, and impulses likely to upset or harm others and violate social norms): Elementary school is the first step toward formal socialization for many children. In school, they learn the rules, behavior, and social skills necessary for participating in group activities with peers of their own age and adults outside their familiar social environment (Doi, 1973).

During recess in a school playground, a boy became impatient while waiting for his turn to use a swing. He got into fight with others. During a tug of war over the swing, the swing accidentally hit the head of one boy. The impatient boy, realizing that his actions led to this accident, apologized to the injured boy. (Teaching to respect the rules of taking turns in the $2^{\text {nd }}$ grade moral book)

A boy talks about his father who runs a sake (Japanese liquor) store. He describes how hard his father works on weekends. He sees his father, soaked in sweat, deliver heavy crates of sake. He and his sister always see their father off when he goes out for delivery. He loves his father very much. (Teaching love and appreciation for hard-working parents in the $3^{\text {rd }}$ year moral book)

Self-direction (Independent thought and action, choosing, creating and exploring, needs for control, independence and autonomy): Self-direction includes values of "freedom", "creativity", "curiosity" and "independence". Independent thought and action in the Japanese moral books are often related to "working hard", "being "diligent", "self-reliance" and "resilience". The moral stories teach that children shall set up their own goals and that that any goal is attainable with 
sufficient efforts. Endurance and perseverance are much sought-after personal traits in Japanese society and children in school are taught to try their best in any endeavor be it studies or sports (Obi, 1981; Singleton, 1991).

\begin{abstract}
A boy is practicing at an iron bar as part of PE class. He is having difficulty in mastering a certain skill, but never gives up. He tries and tries with tears in his eyes until he finally masters the skill. The smile on his face shines like a gold medal around his neck (a story teaching "endeavor" in the 1st-grade moral book.)
\end{abstract}

\begin{abstract}
A group of children have decided to collect empty cans for recycle to help schools in Laos. They place recycling bins for empty cans in town and distribute flyers soliciting help from people. A month later, one boy went to collect cans but none of his friends came. Deeply discouraged, the boy thought about giving up the recycling project. Instead, he held a meeting with his friends and they all decided to continue the project. (Teaching persistence in the $5^{\text {th }}$ grade moral book)

A nurse cares for a boy lying in bed unconscious as the result of a head injury. The nurse tries various methods to treat the boy but none works. He searches for a new method, studying on his own and also making inquiries abroad. One day he reads an article suggesting a new method. He tries the method and it has worked. In a few months the boy starts walking and speaking. (Teaching initiatives and persistence in the $5^{\text {th }}$ grade moral book)
\end{abstract}

The moral books contain values of being "inquisitive" and "inventive" relating to Self-direction. Japan like other post-industrial societies has an urgent need for the type of education that will develop individual's creativity and critical thinking. The moral books understandably emphasize inculcating these values.

Tradition (respect, commitment and acceptance of the customs and ideas and beliefs that one's culture or religion provides): Tradition and Conformity value types share a common interest, both entailing subordination of self in favor of socially imposed expectations and norms. The difference between the two is that Conformity entails subordination to persons in frequent interactions such as parents and teachers whereas Tradition is subordination to abstract ideas of religious and cultural customs in general (Schwartz, 1992, 1994). Tradition emerged from the moral books mostly related to the traditional cultural practices found in Japanese society, such as festivals and the tea-ceremony. Festivals are frequent events throughout the year in Japan. These are rituals observed in the Buddhism and Shinto traditions, dedicated to the spirits or gods residing in nature taking various forms and the souls of the dead.

A boy tells a story of his town festival that started 350 years ago. The festival is to thank an officer of the law at the time who dug a pond to save famers from drought which had brought much suffering and poverty to the people of his region. Hearing the story, the boy becomes more anxious to join the festival (a story teaching "tradition" in the 3rd-grade moral book.)

Security (Safety and stability of society, relationships and self): In the moral books, value items such as "tidy," "healthy" and "environmental beautification" comprised the Security value type. Health is the foundation of a safe society and public health is made possible by healthy individuals and keeping public places clean (NIER, 2013).

A boy on the way to school sees an old man picking up trash in the street. The old man tells the boy that he cleans the street once a week. One day, the boy sees an empty can in the street. He suggests to his friends that they clean up the street together, but nobody shows interest. The boy goes to bed determined to clean the street the following day even if alone. He brings a trash bag and starts cleaning up the street. Seeing him, his friends join him cleaning up the street (a story teaching clean in the $4^{\text {th }}$-grade moral book).

Power, Achievement, Hedonism and Stimulation value types are completely absent in the moral books. Buddhism teaches that the origin of suffering lies in craving for things expected to bring pleasure and that cessation of suffering comes from freedom from attachment, desires and wants (Hirosawa, 2006). This Buddhist ideal of controlling selfindulgent, self-gratifying and pleasure-seeking tendencies may relate to the omission of Hedonism and Stimulation in the moral books. The absence of Power and Achievement types of values may also relate to the Buddhism teaching of knowing and accepting one's place suppressing competition.

\title{
6. Discussion
}

The controversy over Japanese moral education has been played out mainly in the political and ideological arenas. Today, a dispute over moral education among politicians, scholars, educators, the Teachers' Union, citizens and parents in the country, and concerned observers outside the country continues. The discussions are often highly emotional, 
creating schisms among camps claiming nationalism or anti-nationalism, conservative or liberal, and right or wrong. As a national educational policy, Japanese moral education should be scrutinized to avoid repeating the mistakes of the past, and the current open and public discussion on the subject is a worthwhile endeavor to maintain the nation on the intended "moral" course.

When the values underlying the Japanese moral books are examined against the norms of universal human values, the results show that Japanese moral values are consistent with those recognized by cultures around the world both in value contents and hierarchy. This pan-cultural value structure is evident in the Japanese elementary-school moral books as seen in their emphasis on the importance of benevolence, universalism, conformity, tradition, and security. However, the Japanese elementary-school moral books also contain elements that suggest culture-specific values distinct from the ten universal values. These culture-specific elements constitute the traditional Japanese cultural values and spiritual foundations tied to Confucianism, Buddhism, and Shinto.

The present study employed a theoretical framework of universal values as a springboard. The framework was developed from a vantage outside the culture, mainly the western culture and constructed in such way that would apply equally well to all cultures. It does not necessarily represent a whole value system as understood and practiced by cultural insiders. Values are intricately linked to the culture of a society. Values are cultural inheritances acquired through interactions with an environment in which people are born and the process continues throughout their lifetimes (Hofstede \& Bond, 1988). Parts of the world have values irrelevant to the western culture which therefore, are not registered. The Confucian ethos in the eastern culture has been identified one such example (Bond, 1988). Traditional Japanese cultural values were founded on Confucianism, Buddhism, and Shinto. The Japanese moral books reveal values relating to these three cultural and spiritual foundations.

\subsection{Traditional Japanese Cultural Values}

While the values presented in the Japanese moral books are explained by universal human values, other values conspicuously absent from the moral books may be explained by Confucianism and Buddhism tenets. In terms of value classification, the separation between Confucianism and Buddhism is blurred. Both co-exist in the country since they do not significantly mutually conflict, rather, in practice complementing each other; Confucianism for affairs of birth and Buddhism for matters of death, and Confucianism for life on earth and Buddhism for life after death. Both Confucianism and Buddhism teachings praise moderation while admonishing excess, both encourage harmony while discouraging competition, both find the meaning of life in changing or conquering the self not in changing the world. Values associated with changes, achievement and power are suppressed. Indeed, the moral stories examined in the present study lack childlike excitement, adventure, curiosity, and discovery, and most stories take place in familiar places with familiar people playing their familiar roles. The moral stories are predictable and didactic with little room left for children's dynamic inquires and engagement. This raises concerns for the development of "creativity", "individuality", and "zest for life" as discussed in the revised Fundamental Law of Education.

The relative importance of Self-direction embodying individuality, choice, and freedom may contradict with the commonly-held notion of Japan as a collectivistic society. However, the language of effort and hard work expressing selfdirection strongly echoes the Confucian ethos. Berling (1996) explains the outer and inner sides of Confucianism. The outer side of Confucianism relates to conformity and acceptance of social roles; the inner side of Confucianism to cultivation of character, involving education and hard work. Confucianism teaches conformance to society while reforming the self. Moral education in the Meiji era was referred as "training or controlling self" (shüshin). Self-direction understood as reforming the self may not be compatible with the western idea of children fulfilling their potential to become independent and autonomous individuals capable of taking charge of their own life. Traditionally, Japanese define the country in opposition to the individual rather than constituted by individuals (Saito \& Imai, 2004). This particular ideology legitimizes education as a means to "reform" individuals. The Japanese moral education examined in the present study does not sufficiently address the importance of individual growth and development that allow children to explore possibilities on their own. As suggested by Khan (1999) Japan needs to find a way to integrate ideals of individualism with the long-held tradition of Confucianism.

Shintō's influence on the Japanese moral books is evident in a number of stories revealing reverence or awe for nature and lives of people and animals. Shintō (the path of deities) is an indigenous tradition to Japan, recognizing the power of nature primarily associated with natural forces such as wind, lightning, fire; geographical formation of mountains, rocks, trees, and animals and plants as well as the souls of the dead (Littleton, 2002). In essence, Shintō, like animism, recognizes divine spirits everywhere and in every being, in nature and in people, and thereby commands 
respect for all beings in the universe. The protection of environment and unity with nature are part of the universal human values; however, they do not appear to embrace the spiritual concept of nature as Shintō beliefs do. Päivi (2011) studied the 2002 MEXT guidelines for the moral education Notebook of the Heart (Kokoro no Nōto) found three themes concerning natural-supernatural values of "living with nature", "appreciating and protecting the life of every creature", and "feeling a higher power and being awed", all quite similar to the findings of the present study.

The present study shows that the Japanese moral values presented in the moral books are transcending in that they are compatible with the universal values. At the same time, the Japanese moral values have certain peculiarities that could be accounted for only by the Japanese spiritual tradition. The spiritual background based on Confucianism, Buddhism, and Shintō has served as the source of inspiration throughout the history when the country's social order was questioned.

\subsection{Japanese Moral Values as Spiritual Foundations}

Japan has undergone major social and cultural changes at various points in its long history. Often, contacts with the outside world, particularly the western cultures, provided an impetus for such changes. The Meiji Period (1868-1912) and the years following World War II are two prominent examples. At each time, Japan ardently engaged in cultural borrowing and adaptation with goals reflecting particular needs and tastes of the country at the time. Rappleye and Kariya (2011) describe Japan's cultural borrowing and adaptation in modern history as a complex process of "selection, accommodation, balancing, reaction and appraisal" (p. 52). Japan has allowed to enter and circulate that which is considered absorbable on its native soil while maintaining that which is believed to be inalienably Japanese and to be kept pristine from outside influence. The term WaYō Secchü (Japan-West Integration) implies such permeability of the western culture in Japanese everyday life. Another term Wakon Yōsai (Japanese spirit and Western knowledge) well describes what the West represents to Japan and Japan's relationship to the west; Japan represents spiritual culture whereas the West represents materialistic culture. Moral education serves as a means to maintain what is believed to define Japan.

The most recent revival of moral education in Japan may be interpreted as another attempt to define the national identity (Rappleye \& Kariya, 2011). The years following the end of the war were mostly spent catching up with the West mainly America. In Japanese minds, Japan was defeated by American bombs on Hiroshima and Nagasaki, not by the Asian countries that Japan occupied. With this frame of mind, Japan directed its efforts toward catching up with and surpassing America economically (Rappleye and Kariya, 2011). In the 1970s when Japan had essentially "caught up" with America economically, the country lost "others" to emulate for models and started wandering in search of "self". In the 1990s, with the wave of globalization reaching Japan, the country started searching for "self" in the face of highly ambiguous "others". The Course of Study (MEXT, 2008) states as one goal of moral education to develop "selfawareness of being Japanese in the world and the awareness that Japanese people contribute to world peace and human happiness." Here, the statement communicates Japan's attempts to know "self" to properly position the nation among "others" in the global world. The revised Fundamental Law of Education under which this particular Course of Study was published directs among other things "to respect traditional cultures and love for one's own country and hometown that have nurtured those cultures." This statement reveals Japan's stance that a secure self-identity is the foundation for globalization. Globalization empowers, rather than weakens the country (Willis and Rappleye, 2011). In the framework of the universal human values, survival of a group is a strong motivator for people to pursue values strengthening unity and cohesion of the group. Resurgence of moral education may be understood as Japan's reaction to the force of globalization.

Moral education in Japan has been and will continue to constitute a core goal of education, officially and unofficially, and its policy and contents will continue to be scrutinized by observers in and outside the country. Values can be examined and understood from various perspectives. The present study examined the Japanese moral values from cultural perspectives at a culture-universal level as well as country-specific level, hoping to add a new dimension to the debate on the topic.

\section{Conclusion}

In the present study Japanese moral values are treated as synonymous to Japanese cultural values for their inextricable relationship. A country's values, moral or cultural, are better understood by comparison with other countries. The global world will provide researchers greater opportunities for discussion on what moral values constitute ideal citizens from 
various cultural and social perspectives. Values of human relationship, duty, obligation, and work ethics were an engine for Japan's recovery after the war (Hofstede \& Bond, 1988). Virtues of patience and endurance were evident in people patiently waiting in long food lines after the devastation of earthquake and tsunami in 2011. Rejection of moral values uninformed by awareness of cultural context and driven by doubts and suspicion will lead to stereotyping and subjugation of the values of others. Indeed, the challenges of promulgating ideals of a democratic society in the aftermath of war are more relevant than ever in the modern world. The total negation of the values identified as Japanese and therefore undemocratic may have contributed to Japan's lost wandering after the war. Meanwhile, a big challenge lies ahead as Japan's search for "self" continues. The Course of Study calls for maintenance of the Japanese tradition and Japan's commitment to the global community. The dualism of searching for "self" while connecting with "others" may be interpreted as Japan's hope to affirm its position in such way acceptable to the rest of the world. The absence of direct references to nationalism and militarism in the Japanese moral books examined in the present study attests such an interpretation.

\section{References}

Allport, G.W. (1961). Pattern and growth in personality. New York: Holt, Rinehart \& Winston.

Berling, J.A. (1996). Confucianism. Focus on Asian Studies, 2 (1), 5-7.

Bond, M. H. (1988). Finding dimensions of individual variation in multicultural studies of values: the Rokeach and Chinese value surveys. Journal of Personality and Social Psychology, 55(6), 1009-1115.

Doi, T. (1973). Amae no kozo [The anatomy of dependence]. Tokyo: Kodansha International.

Graneheim, U.H. \& Lundman, B. (2004). Qualitative content analysis in nursing research: Concepts, procedures and measure to achieve trustworthiness. Nurse Education Today, 24 (2),

Hirosawa, T. (2006). Yoku wakaru bukkyo [Comprehensible Buddhism] Kyoto: PHP Institute.

Hoffman, S. D. (1999). School texts, the written word, and political indoctrination; a review of moral education curricula in modern Japan (1886-1997). History of Education, 28(1), 87-97.

Hofstede, G. and M.H. Bond (1988). The Confucian connection: Form cultural roots to economic growth. Organizational Dynamics, 1 (4), 4-21.

Jahanbeglo0, Ramin, (1991). Conversations with Isaiah Berlin. McArthur \& Co. Reprinted 2007, Halban Publishers.

Khan, Y. (1997). Japanese moral education past and present. Madison: Fairleigh, Dickinson University Press.

Kluckhohn, C. (1951). Values and value-orientations in the theory of action: An exploration in definition and classification. In T. Parsons \& E. Shils (Eds.), Toward a general theory of action (pp.388-433). Cambridge, MA: Harvard University Press.

Littleton, S. C. (2002). Shinto: Origins, Rituals, Festivals, Spirits, Sacred Places. Oxford University Press, Inc.

Luhmer, K. (1990). Moral Education in Japan. Moral Education, 19 (3), 172-182.

Ministry of Education, Culture, Sport, Science and Technology (MEXT) (2006). Concerning Amendment of Fundamental Law of Education. Retrieved from http://www.mext.go.jp/b_menu/kihon/houan.htm

Ministry of Education, Culture, Sports, Science and Technology Japan (MEXT) (2008). Gakusyū shiōo yōryō [The Course of Study for elementary school]. Retrieved from http://www.mext.go.jp/a_menu/shotou/new-cs/youryou/syo/index.htm

McVeigh, B. (1998). Linking state and self: How the Japanese State Bureaucratizes Sujectivity through Moral Education. Anthropological Quarterly, 71 (3), 125-137.

McVeigh, D. (2008). Moral and social education in Japanese schools: Conflicting conceptions of citizenship. Citizenship Teaching and Learning, 4 (1), 21-34.

Monai, Y. \& Sato, S. (2012). Meiji zenki ni okeru dōtoku kyōiku to shakai kyoikū no kankei ni kansuru ichi kosatsu [Study of the relation between moral education and social education in the early Meiij era]. Hirosaki Daigaku Kyōikugakubu Kiyō, 107, $123-129$.

National Institute for Educational Research Policy (NIER) (2013). Shōgakō hoken keikaku jissi yōkō [A summary of elementary school health plan]. Retrieved from http://www.nier.go.jp/guideline/s25ep/

Nitobe, I. (1969). Bushido: The Soul of Japan. Rutland, Vermont: Charles E. Tuttle Company

Obi, T. (1981). Hachiju nendai no kyoiku: Dotoku-sei to kokusai-sei [Education in 1980s: Morality and Internationalism]. Tokyo: Meiji Tosho Shuppan.

Päivi, P. (2011). Moral Education in the Japanese Primary School Curricular Revision at the Turn of the Twenty-first Century: Aiming at a Rich and Beautiful Kokoro (Doctoral dissertation). Retrieved from http://urn.fi/URN:ISBN:978-952-10-6839-3

Rappleye, J. and T. Kariya (2011). Reimagining Self/Other: 'Catch-up' across Japan's three great education reforms. In D. B. Willis \& Jeremy Rappleye (Eds.) Reimagining Japanese Education: Borers, Transfers, Circulations, and the Comparative (pp. 51-84). Oxford: Symposium Books.

Report of the United States Educational Mission to Japan: Submitted to the Supreme Commander for the Allied Powers, Tokyo, Japan (March 30, 1946). Washington DC: Printing Office.

Rokeach, M. (1973). The nature of human values. New York: Free Press.

Saito, N., and Y. Imai (2004). In search of the public and the private: Philosophy of Education in post-war Japan. Comparative Education, 40 (4), 583-594. 
Sasaki, A. (1999). Dōtoku kyōiku no kenkyū [Studies on moral education]. Tokyo: Gakugeisha

Schwartz, S. H. (1992). Universals in the content and structure of values: Theory and empirical tests in 20 countries. In M. Zanna (Ed.), Advances in experimental social psychology (Vol. 25) (pp. 1-65). New York: Academic Press.

Schwartz, S. H. (1994). Are there universal aspects in the content and structure of values? Journal of Social Issues, 50, 19-45.

Schwartz, S. H. (2006). Basic Human Values: Theory, Measurement, and Application. Retrieved from http://ccsr.ac.uk/qmss/seminars 12009-06-10/documents/Shalom_Schwartz_1.pdf

Schwartz, S. H., \& Bardi, A. (2001). Value hierarchies across cultures: Taking a similarities perspective. Journal of Cross-Cultural Psychology, 32, 268-290.

Schwartz, S. H. and W. Bilsky (1987). Toward a Universal Psychological Structure of Human Values. Journal of Personality and Social Psychology, 53, 550-562.

Schwartz, S. H., \& W. Bilsky. (1990). Toward a theory of the universal content and structure of values: Extensions and cross-cultural replications. Journal of Personality and Social Psychology, 58, 878-891.

Singleton, J. (1991). The spirits of gambarism. In B. Finkelstein, A. E. Imamura \& J. J. Tobin (Eds.), Transcending stereotypes (pp. 119125). Yarmouth, ME: Intercultural Press.

Tamura, S. (2009). Dōtoku kyōiku ni okeru aikokushin [Patriotism and moral education], Seisen Jogakuin Daigaku Ningengakubu Kenkyū Kiyō, 6, 49-58.

Uetsugu, H. (2010). Jidō muke syōgakkō dōtoku fukudokuhon ni okeru fukushi mondai [The issues of benevolence in moral readers for children]. Shitennoji Daigaku Kiyō, 50, 377-409.

Umehara, T. \& Inamori, K. (2005). Atarashii testugaku o kataru [Essays on new philosophies] Kyoto, Japan: PHP Institute.

Willis, D.B. and J. Rappleye (2011). Reimagining Japanese Education in the Global Conversations: borders, transfers, circulations, and the comparative. In D.B. Willis and J. Rappleye (Eds.), Reimagining Japanese Education: Borers, Transfers, Circulations, and the Comparative (pp. 15-49). Oxford: Symposium Books. 